\title{
Identification of Risks Pertaining to Abandoned Housing Projects in Malaysia
}

\author{
Hamzah Abdul-Rahman, Chen Wang, and Nur Hamizah Ariffin
}

Faculty of Built Environment, University of Malaya, 50603 Kuala Lumpur, Malaysia

Correspondence should be addressed to Chen Wang; derekisleon@gmail.com

Received 22 June 2015; Revised 24 October 2015; Accepted 25 October 2015

Academic Editor: F. Pacheco-Torgal

Copyright @ 2015 Hamzah Abdul-Rahman et al. This is an open access article distributed under the Creative Commons Attribution License, which permits unrestricted use, distribution, and reproduction in any medium, provided the original work is properly cited.

\begin{abstract}
Housing industry is one of the most dynamic, risky, and challenging industries. In Malaysia, this industry has a poor reputation for managing risks, with many major projects failing to be completed within the allotted time. Due to the inherent risks involved in construction projects, it is essential to recognize the risks that cause problems associated with abandoned housing projects. Therefore, this study aims to identify the risks that contribute to issues of abandoned housing projects and to propose mitigation strategies. The methodologies used in this study are combination of qualitative and quantitative methods of literature review, questionnaire survey, and interview. The results show that many risks are involved in housing project, including risks related to environmental impacts, construction, politics, law, management, finance, materials, and economy, of which the probability of risks from unexpected ground condition, project delays, bureaucracy, contractual disputes between developer and landlord, weakness in management by inexperience developer, and financial crisis is very high. It was also found that all relevant parties involved in housing industry are required to have extensive cooperation in advance and should perform systematic risk management strategies in order to mitigate the risks leading to problems associated with abandoned housing projects.
\end{abstract}

\section{Introduction}

A housing project is generally defined as abandoned when the construction project is not completed and ready for occupation on schedule. The abandoned housing projects can bring both environmental and socioeconomic impacts. Those of socioeconomic nature include loss of jobs, loss of value of the area, marginalization of population, and transfer of cost between private and public sector, and those of environmental nature include visual impact, landscape modification, erosion, loss of biodiversity, and pollution [1]. The risks in housing construction project are sometimes inevitable and it is, therefore, the responsibility of the parties involved in construction industry (i.e., consultant, owner, and/or contractor) to identify these risks as early as possible to minimize the potential losses [2,3]. Moreover, according to [4], sometimes although the risks have already been predicted, it is still difficult and challenging to manage them. The causes of abandoned housing projects seem to vary in different countries; however, one common reason for that is mainly due to the unforeseen factors resulting from the initial misestimation of project costs by developers of the housing project during the planning stage [5-8]. Previous studies have shown that mismanagement, unfavorable government policies, inefficient public delivery system, unfavorable economic conditions, and financial problems are the major causes of the abandoned housing projects [9].

In Malaysia, the construction industry has been criticized for its project delays, increasing costs, low productivity, unsafe site conditions, and poor quality. It has also been highlighted that internal management problems create negative impacts which result in abandoned housing projects, and, thus, effective risk management is required in implementing any construction activities to monitor the risks and develop the strategies to mitigate the impacts [10]. The construction sector, in Malaysia, has struggled with financial difficulties which have led to many problems associated with abandoned housing projects. Housing industry is one of the most dynamic, risky, and challenging businesses which contributes to the domestic wealth. More importantly, housing industry has been a major contributor to the Malaysian economy and, ultimately, it has a multiplier 
effect on other industries which support housing industry [11].

The construction industry in Malaysia has a poor reputation for managing risks, with many major projects that failed to be completed within the specified time frames of the project. Abandoned housing projects are not unique to Malaysia as it is considered as a major problem in construction industry in many other countries including US, Spain, Russia, Dubai, and Kuwait [9]. However, the problems associated with abandoned housing projects in Malaysia have been plaguing long enough at a scale that deserves a great attention [12]. It was reported that between 1990 and 2005 , there were total of 261 abandoned housing projects in Malaysia involving 88,410 houses. State of Selangor, in particular, had the most number of abandoned projects, whereby 63 projects involving 32,987 houses affected 22,480 buyers. Even though the number has been gradually decreased, it was reported that, in 2010, there were still over 45,339 units of abandoned houses which would require RM3 to RM5 billion for the projects to be completed [13].

Every construction project might face some major risks, including costs overrun, schedule delay, unsafe working environment, and low quality of product. As a result, the problems associated with abandoned housing projects can pose serious problems to the government (national, state, and local government), bankers, purchasers, and developers [14]. Although the government of Malaysia has intervened in an attempt to overcome the problems associated with abandoned housing project through rehabilitation programme for those projects having the potential to be revived, as well as a few regulatory actions for preventing future abandoned housing projects, the issues related to abandoned housing projects are still unresolved [15]. Therefore, this study aims to identify the risks pertaining to abandoned housing projects and to recommend mitigation strategies.

\section{Research Methodologies}

The methodologies used for this study are combination of literature review, questionnaire survey, and interview in order to obtain the necessary information about the abandoned housing projects in Malaysia. Based on the results obtained from the methodologies, each factor that has led to problems associated with abandoned housing projects was analyzed accordingly.

2.1. Literature Review. The literature review was carried out to obtain the necessary information regarding the risks pertaining to housing industry in Malaysia. By conducting the literature review, we were able to see the broad perspective of the abandoned housing projects, to find the actual situation of abandoned housing projects, and to acquire the opinion of other researchers toward the same problems.

2.2. Questionnaire. For this study, the questionnaire survey was used to investigate and identify the risks associated with abandoned housing projects. A questionnaire survey was prepared and distributed among the selected respondents.
2.2.1. Preparation and Distribution of Questionnaire Form. A set of questionnaire forms was designed carefully in order to make sure all the questions are related to our objectives. The questionnaire survey form was divided into two sections, that is, Sections A and B. Section A focuses on the professionals' background and Section B focuses on identifying the risks associated with abandoned housing projects. All the information obtained from the respondents was kept in the strict and confidential manner. The respondents were required to circle or tick on the appropriate blank according to the scale given for the probability of risks. Number 1 represents very low probability, number 2 represents low probability, number 3 represents moderate probability, number 4 represents high probability, and number 5 represents very high probability. The results were then analyzed according to the percentage of the responses. A total of 80 copies of questionnaire form were prepared and distributed amongst the selected respondents who have been involved in housing industry.

2.2.2. Respondents Selection. The selected respondents are from Ministry of Housing and Local Government (MHLG), Syarikat Perumahan Negara Berhad (SPNB), and the private agencies such as consultants and developers. The questionnaire forms were distributed to the selected firms either personally or via emails.

2.3. Interview. In addition to the questionnaire survey, the interview session was held in order to meet the objectives of the study and gather more necessary information about the problems associated with the abandoned housing projects in Malaysia. The interview was carried out with developers and the other professional parties in housing industry. During the interview session, the respondents were asked few questions and encouraged to give their own perception and opinion. Therefore, the data gathered is all about knowledge, awareness, ideas, and opinions on abandoned housing projects in Malaysia.

\subsubsection{The Preparation and Distribution of Interview Survey} Form. The interview form was prepared based on the issues obtained from the literature review and the results of the survey studies. The distribution of interview form was carried out personally, and an appointment was held through a phone call.

2.3.2. Respondents Selection. The selected respondents are from government, private agency, developer, and contractor. In terms of positions, the respondents were chosen according to their experience and influence in their organization.

\section{Data Analysis and Results}

The issue of abandoned housing projects is not a new phenomenon in Malaysia. In fact, it has been identified since 1983 as a significant problem to be addressed. This study, to a degree one study can, provided information about the relevant risks pertaining to abandoned housing projects, 
as well as the proposed strategies to manage the risks associated with abandoned housing projects.

3.1. Questionnaire. Out of 80 questionnaires distributed among developers, consultants, local authorities, and others, 40 responses were collected. The data were analyzed by using the cross tabulation and linear regression of Statistical Package for Social Science (SPSS) as it is recognized as the most suitable tool in analyzing the data from a large sample.

3.1.1. Respondents Background. The details of the respondents involved in the questionnaire survey (Section A) are provided in Tables 1 and 2. Both tables present the information about the gender of respondents, age of respondents, type of organization, level of education, and working experience of respondents. The total number of respondents is 40 , of which 9 respondents are developers, 8 respondents are contractors, 15 respondents are from local authorities, and 8 respondents are others. The results show that most of respondents are male and have a degree and majority of them aged between 30 and 39 years old and have working experience in industry for at least 10 years.

3.1.2. Respondents Response on Risk Factors. Based on the results obtained from Section B of the questionnaire survey, factors pertaining to housing projects abandonment can be categorized as follows: environmental impacts, construction, politics, law, management, and finance. The details of each factor are presented in Tables 3-8 and discussed hereunder.

Environmental Impacts. Environmental impact is one of the risks that need to be taken into consideration by parties involved in housing industry. Although this risk might not occur in every project, if it happens, it will have severe negative effects on the housing projects. By using the descriptive frequency tables, the factors related to environmental impacts (Force Majeure, unexpected ground condition, lightning strike, heavy raining, and pollutions) were analyzed (Table 3 ).

Almost $37.5 \%$ of respondents believed that Force Majeure and heavy raining have a moderate probability while almost half of them agreed that lightning strike and pollution have a low probability. The results indicate that Force Majeure and heavy raining are not considered as serious risks in abandoned housing projects in Malaysia. In fact, environmental impacts such as flood, storm, and heavy continuous rain usually occur in raining seasons in Malaysia not throughout the year, and the developers are generally prepared to handle the construction works under such environmental conditions.

On the other hand, almost half of the respondents (47.5\%) agreed that the probability of unexpected ground condition is high. This risk, which may occur during the construction project, is considered high and might subsequently result in project delay and cost overrun.

Construction. There are many factors in the process of housing construction which may cause major risks. There are five risks recognized under the category of construction, which are delay of project, shortage of labour/manpower, shortage
TABLE 1: Cross tabulation of type of organization, gender, and age of respondents.

\begin{tabular}{|c|c|c|c|c|c|}
\hline \multirow{2}{*}{$\begin{array}{l}\text { Type of } \\
\text { organization }\end{array}$} & \multirow{2}{*}{$\begin{array}{l}\text { Gender of } \\
\text { respondents }\end{array}$} & \multicolumn{3}{|c|}{$\begin{array}{c}\text { Age of respondents } \\
\text { Total }\end{array}$} & \multirow[t]{2}{*}{ Tota } \\
\hline & & Below 30 & $30-39$ & $40-49$ & \\
\hline \multirow{3}{*}{ Developer } & Male & & 4 & 1 & 5 \\
\hline & Female & & 2 & 2 & 4 \\
\hline & Total & & 6 & 3 & 9 \\
\hline \multirow{3}{*}{ Consultant } & Male & 3 & 7 & & 10 \\
\hline & Female & 0 & 5 & & 5 \\
\hline & Total & 3 & 12 & & 15 \\
\hline \multirow{3}{*}{$\begin{array}{l}\text { Local } \\
\text { authority }\end{array}$} & Male & 0 & 7 & 1 & 8 \\
\hline & Female & & 0 & 0 & 0 \\
\hline & Total & & 7 & 1 & 8 \\
\hline \multirow{3}{*}{ Others } & Male & & 1 & 5 & 6 \\
\hline & Female & & 0 & 2 & 2 \\
\hline & Total & & 1 & 7 & 8 \\
\hline
\end{tabular}

TABLE 2: Cross tabulation of type of organization, working experience, and level of education.

\begin{tabular}{|c|c|c|c|c|c|}
\hline \multirow{2}{*}{$\begin{array}{l}\text { Type of } \\
\text { organization }\end{array}$} & \multirow{2}{*}{$\begin{array}{l}\text { Working } \\
\text { experience }\end{array}$} & \multicolumn{3}{|c|}{ Level of education } & \multirow{2}{*}{ Total } \\
\hline & & Diploma & Degree & Master & \\
\hline \multirow{4}{*}{ Developer } & $<10$ years & & 2 & & 2 \\
\hline & $11-19$ years & & 4 & & 4 \\
\hline & $20-30$ years & & 3 & & 3 \\
\hline & Total & & 9 & & 9 \\
\hline \multirow{3}{*}{ Consultant } & $<10$ years & 3 & 4 & & 7 \\
\hline & $11-19$ years & 0 & 8 & & 8 \\
\hline & Total & 3 & 12 & & 15 \\
\hline \multirow{3}{*}{$\begin{array}{l}\text { Local } \\
\text { authority }\end{array}$} & $11-19$ years & & 7 & 0 & 7 \\
\hline & $20-30$ years & & 0 & 1 & 1 \\
\hline & Total & & 7 & 1 & 8 \\
\hline \multirow{3}{*}{ Others } & $11-19$ years & 0 & 1 & & 1 \\
\hline & $20-30$ years & 2 & 5 & & 7 \\
\hline & Total & 2 & 6 & & 8 \\
\hline
\end{tabular}

of equipment, low performance by labour, poor construction planning by contractor, and failure in managing construction activities by contractor. By the use of descriptive frequency, these factors were analyzed (Table 4).

All respondents believed that the probability of delay of project is either high or very high in the housing projects, which indicates that the incident of delay of project is a risk that required all parties to be careful and take appropriate actions to mitigate it. The delay of housing project is usually caused by contractors who failed to fulfill the components involved in the construction process. For instance, some contractors failed to handle the problems such as shortage of materials or manpower at site due to the underestimation. This situation most likely causes delays of project in a certain period and might lead the project to become abandoned. 
TABLE 3: Response on environmental impacts.

\begin{tabular}{|c|c|c|c|c|c|}
\hline Environmental impacts & Probability & Frequency & Percent & Valid percent & Cumulative percent \\
\hline \multirow{6}{*}{$\begin{array}{l}\text { Force Majeure, such as } \\
\text { earthquake, flood, and } \\
\text { storm }\end{array}$} & Very low probability & 3 & 7.5 & 7.5 & 7.5 \\
\hline & Low probability & 13 & 32.5 & 32.5 & 40 \\
\hline & Moderate probability & 15 & 37.5 & 37.5 & 77.5 \\
\hline & High probability & 7 & 17.5 & 17.5 & 95 \\
\hline & Very high probability & 2 & 5 & 5 & 100 \\
\hline & Total & 40 & 100 & 100 & \\
\hline \multirow{6}{*}{$\begin{array}{l}\text { Unexpected ground } \\
\text { condition }\end{array}$} & Very low probability & 2 & 5 & 5 & 5 \\
\hline & Low probability & 3 & 7.5 & 7.5 & 12.5 \\
\hline & Moderate probability & 5 & 12.5 & 12.5 & 25 \\
\hline & High probability & 19 & 47.5 & 47.5 & 72.5 \\
\hline & Very high probability & 11 & 27.5 & 27.5 & 100 \\
\hline & Total & 40 & 100 & 100 & \\
\hline \multirow{6}{*}{ Lightning strike } & Very low probability & 6 & 15 & 15 & 15 \\
\hline & Low probability & 22 & 55 & 55 & 70 \\
\hline & Moderate probability & 10 & 25 & 25 & 95 \\
\hline & High probability & 2 & 5 & 5 & 100 \\
\hline & Very high probability & - & & & \\
\hline & Total & 40 & 100 & 100 & \\
\hline \multirow{6}{*}{ Heavy raining } & Very low probability & 2 & 5 & 5 & 5 \\
\hline & Low probability & 8 & 20 & 20 & 25 \\
\hline & Moderate probability & 15 & 37.5 & 37.5 & 62.5 \\
\hline & High probability & 9 & 22.5 & 22.5 & 85 \\
\hline & Very high probability & 6 & 15 & 15 & 100 \\
\hline & Total & 40 & 100 & 100 & \\
\hline \multirow{6}{*}{ Pollution } & Very low probability & 11 & 27.5 & 27.5 & 27.5 \\
\hline & Low probability & 18 & 45 & 45 & 72.5 \\
\hline & Moderate probability & 11 & 27.5 & 27.5 & 100 \\
\hline & High probability & - & & & \\
\hline & Very high probability & - & & & \\
\hline & Total & 40 & 100 & 100 & \\
\hline
\end{tabular}

The probability of shortage of labour/manpower and low performance by labour are considered moderate which implies that these are not considered as major risks leading to the occurrence of problems associated with abandoned housing projects if they are handled and managed properly. On the other hand, majority of respondents believed that poor construction planning by contractor is a serious risk, such that $50 \%$ of them considered the probability of this risk very high and 35\% considered its probability high. Given that the contractor is an important person who holds essential responsibilities at construction site, any poor planning by him would definitely result in serious problems associated with housing projects. Shortage of equipment is also recognized as an important risk in housing projects whose probability to occur is also high. Although $40 \%$ of respondents still believe this risk has a moderate probability, they all agreed that this risk related to the shortage of equipment should be given a great attention as it is indirectly related to the project delay and cost overrun.
Politics. The political situation in a country plays a very important role in ensuring that the construction projects are implemented properly. Unstable political conditions induce a lot of problems to housing industry. Under this category, the potential risks are the response on unstable political conditions in country, change in government policy, disruption on project by local government, bureaucracy, and suspension of foreign workers by government. By using descriptive frequency the abovementioned risks were analyzed and discussed in order to see whether such risks can be a cause of abandoned housing project (Table 5).

The results of responses on political risks show that half of the respondents believed that unstable political conditions in country as well as bureaucracy are considered as critical risks in housing project in Malaysia with high probability. Such risks directly affect developers and might eventually lead to abandoned housing project. On the other hand, respondents considered change in government policy, disruption on project by local government, and suspension of 
TABLE 4: Response on construction.

\begin{tabular}{|c|c|c|c|c|c|}
\hline Construction & Probability & Frequency & Percent & Valid percent & Cumulative percent \\
\hline \multirow{6}{*}{ Delay of project } & Very low probability & - & & & \\
\hline & Low probability & - & & & \\
\hline & Moderate probability & - & & & \\
\hline & High probability & 19 & 47.5 & 47.5 & 47.5 \\
\hline & Very high probability & 21 & 52.5 & 52.5 & 100.0 \\
\hline & Total & 40 & 100.0 & 100.0 & \\
\hline \multirow{6}{*}{ Shortage of labour/manpower } & Very low probability & 1 & 2.5 & 2.5 & 2.5 \\
\hline & Low probability & 2 & 5 & 5 & 7.5 \\
\hline & Moderate probability & 16 & 40 & 40 & 47.5 \\
\hline & High probability & 13 & 32.5 & 32.5 & 80 \\
\hline & Very high probability & 8 & 20 & 20 & 100 \\
\hline & Total & 40 & 100 & 100 & \\
\hline \multirow{6}{*}{ Shortage of equipment } & Very low probability & - & & & \\
\hline & Low probability & 6 & 15 & 15 & 15 \\
\hline & Moderate probability & 16 & 40 & 40 & 55 \\
\hline & High probability & 17 & 42.5 & 42.5 & 97.5 \\
\hline & Very high probability & 1 & 2.5 & 2.5 & 100 \\
\hline & Total & 40 & 100 & 100 & \\
\hline \multirow{6}{*}{ Low performance by labour } & Very low probability & 7 & 17.5 & 17.5 & 17.5 \\
\hline & Low probability & 14 & 35 & 35 & 52.5 \\
\hline & Moderate probability & 16 & 40 & 40 & 92.5 \\
\hline & High probability & 2 & 5 & 5 & 97.5 \\
\hline & Very high probability & 1 & 2.5 & 2.5 & 100 \\
\hline & Total & 40 & 100 & 100 & \\
\hline \multirow{6}{*}{$\begin{array}{l}\text { Poor construction planning by } \\
\text { contractor }\end{array}$} & Very low probability & - & & & \\
\hline & Low probability & 1 & 2.5 & 2.5 & 2.5 \\
\hline & Moderate probability & 5 & 12.5 & 12.5 & 15 \\
\hline & High probability & 14 & 35 & 35 & 50 \\
\hline & Very high probability & 20 & 50 & 50 & 100 \\
\hline & Total & 40 & 100 & 100 & \\
\hline
\end{tabular}

foreign worker by government as not serious risks leading to problems associated with abandoned housing projects (moderate probability). Change in government policy and disruption on project by local government often occurred when government set up new standard and the parties involved fail to meet such desired standard. Moreover, suspension of foreign worker by government might result in shortage of labour/manpower on construction site and directly affect the construction project's performance. However, these are not the case in Malaysia.

Law. Law is one of the important factors that assist the development of housing projects. All parties involved should have high knowledge in law related to this industry. For this category, some risks are identified such as breach of contract, contractual disputes between developer and landlord, delay in resolving contractual disputes, change in law of housing industry, and lack of knowledge on housing industry law by developer. By the use of descriptive frequency, the risks related to law were analyzed and discussed (Table 6).

Almost half of respondents believed that all risks related to law, except delay in resolving contractual disputes, have a moderate probability in housing project in Malaysia. The results imply that such risks are not considered as major risks contributing to problems associated with abandoned housing project in Malaysia.

Management. Management is another crucial factor in housing development. The management might ensure that the project is well-organized and also completed within budget and time. The risks under this category are weakness in management by inexperienced developer, weakness in management by inexperienced contractor, delay in work due to management failure by third party, risks caused by subcontractor, and partner withdrawals from joint venture. 
TABLE 5: Response on politic.

\begin{tabular}{|c|c|c|c|c|c|}
\hline Construction & Probability & Frequency & Percent & Valid percent & Cumulative percent \\
\hline \multirow{6}{*}{$\begin{array}{l}\text { Unstable political conditions in } \\
\text { country }\end{array}$} & Very low probability & - & & & \\
\hline & Low probability & - & & & \\
\hline & Moderate probability & 11 & 27.5 & 27.5 & 27.5 \\
\hline & High probability & 20 & 50 & 50 & 77.5 \\
\hline & Very high probability & 9 & 22.5 & 22.5 & 100 \\
\hline & Total & 40 & 100 & 100 & \\
\hline \multirow{6}{*}{ Change in government policy } & Very low probability & - & & & \\
\hline & Low probability & 13 & 32.5 & 32.5 & 32.5 \\
\hline & Moderate probability & 22 & 55 & 55 & 87.5 \\
\hline & High probability & 5 & 12.5 & 12.5 & 100 \\
\hline & Very high probability & - & & & \\
\hline & Total & 40 & 100 & 100 & \\
\hline \multirow{6}{*}{$\begin{array}{l}\text { Disruption on project by local } \\
\text { government }\end{array}$} & Very low probability & - & & & \\
\hline & Low probability & - & & & \\
\hline & Moderate probability & 21 & 52.5 & 52.5 & 52.5 \\
\hline & High probability & 19 & 47.5 & 47.5 & 100 \\
\hline & Very high probability & - & & & \\
\hline & Total & 40 & 100 & 100 & \\
\hline \multirow{6}{*}{ Bureaucracy } & Very low probability & - & & & \\
\hline & Low probability & 1 & 2.5 & 2.5 & 2.5 \\
\hline & Moderate probability & 4 & 10 & 10 & 12.5 \\
\hline & High probability & 22 & 55 & 55 & 67.5 \\
\hline & Very high probability & 13 & 32.5 & 32.5 & 100 \\
\hline & Total & 40 & 100 & 100 & \\
\hline \multirow{6}{*}{$\begin{array}{l}\text { Suspension of foreign workers by } \\
\text { government }\end{array}$} & Very low probability & 3 & 7.5 & 7.5 & 7.5 \\
\hline & Low probability & 14 & 35 & 35 & 42.5 \\
\hline & Moderate probability & 18 & 45 & 45 & 87.5 \\
\hline & High probability & 5 & 12.5 & 12.5 & 100 \\
\hline & Very high probability & - & & & \\
\hline & Total & 40 & 100 & 100 & \\
\hline
\end{tabular}

Table 7 shows the results of the descriptive frequency of the abovementioned risks.

Majority of respondents believed that the probability of risks related to management such as weakness in management by inexperienced contractor, delay in work due to management failure by third party, risks caused by subcontractor, and partner withdrawals from joint venture is moderate, and the rest of respondents agreed that the probability of such risks is high. Moreover, half of respondents claimed that the weakness in management by inexperienced developer is considered as a very serious risk (high and very high probability).

From the results it can be concluded that the management generally has a very important role in housing project. An efficient management can assist the project to achieve its desired objectives. Contractor particularly has a fundamental role at construction site, and if not well-organized, the developer will face many problems. For instance, a contractor by a poor planning, such as miscalculation of materials and machinery at construction site, might cause shortage or excess of materials and equipment. As a result, the project will not be completed within the expected time period and subsequently the developer will face an unexpected budget overrun. Risk related to subcontractor also needs to be given a great attention, as poor performance of subcontractor can make the progress of construction activities ineffective and subsequently lead to problems associated with the abandoned housing projects.

Finance. Financial issue is the most important factor which requires a great attention by parties involved in construction industry since a housing project cannot proceed without sufficient financial sources. The risks under this category are late payment to contractor, unstable finance by third party, over budget, bankruptcy by developer, and financial crisis. By using descriptive frequency, financial-related risks were analyzed in order to see if each can be a cause of abandoned housing project (Table 8 ). 
TABLE 6: Response on law.

\begin{tabular}{|c|c|c|c|c|c|}
\hline Construction & Probability & Frequency & Percent & Valid percent & Cumulative percent \\
\hline \multirow{6}{*}{ Breach of contract } & Very low probability & - & & & \\
\hline & Low probability & 7 & 17.5 & 17.5 & 17.5 \\
\hline & Moderate probability & 24 & 60 & 60 & 77.5 \\
\hline & High probability & 8 & 20 & 20 & 97.5 \\
\hline & Very high probability & 1 & 2.5 & 2.5 & 100 \\
\hline & Total & 40 & 100 & 100 & \\
\hline \multirow{6}{*}{$\begin{array}{l}\text { Contractual disputes between } \\
\text { developer and landlord }\end{array}$} & Very low probability & - & & & \\
\hline & Low probability & 2 & 5 & 5 & 5 \\
\hline & Moderate probability & 22 & 55 & 55 & 60 \\
\hline & High probability & 16 & 40 & 40 & 100 \\
\hline & Very high probability & - & & & \\
\hline & Total & 40 & 100 & 100 & \\
\hline \multirow{6}{*}{ Delay in resolving contractual disputes } & Very low probability & 15 & 37.5 & 37.5 & 37.5 \\
\hline & Low probability & 17 & 42.5 & 42.5 & 80 \\
\hline & Moderate probability & 8 & 20 & 20 & 100 \\
\hline & High probability & - & & & \\
\hline & Very high probability & - & & & \\
\hline & Total & 40 & 100 & 100 & \\
\hline \multirow{6}{*}{ Change in law of housing industry } & Very low probability & 2 & 5 & 5 & 5 \\
\hline & Low probability & 12 & 30 & 30 & 35 \\
\hline & Moderate probability & 18 & 45 & 45 & 80 \\
\hline & High probability & 5 & 12.5 & 12.5 & 92.5 \\
\hline & Very high probability & 3 & 7.5 & 7.5 & 100 \\
\hline & Total & 40 & 100 & 100 & \\
\hline \multirow{6}{*}{$\begin{array}{l}\text { Lack of knowledge on housing } \\
\text { industry law by developer }\end{array}$} & Very low probability & 10 & 25 & 25 & 25 \\
\hline & Low probability & 7 & 17.5 & 17.5 & 42.5 \\
\hline & Moderate probability & 13 & 32.5 & 32.5 & 75 \\
\hline & High probability & 3 & 7.5 & 7.5 & 82.5 \\
\hline & Very high probability & 7 & 17.5 & 17.5 & 100 \\
\hline & Total & 40 & 100 & 100 & \\
\hline
\end{tabular}

Almost all of financial risks were given high probability by respondents, such that the probabilities of high and very high were given by $70 \%$ of respondents for "over budget" and by all respondents for "bankruptcy by developer." These issues always occur due to the financial failure in organization. Moreover, almost half of respondents believed that late payment to contractor has a high probability and financial crisis has a very high probability. Hence, these risks can be considered as major causes of abandoned housing projects. For unstable finance by third party, a moderate probability was given by $37.5 \%$ of respondents indicating its less serious aspect in regard to the housing projects compared to others.

3.1.3. Linear Regression Analysis. A linear regression analysis, using SPSS software, was computed in order to determine which construction risks have the most serious impact on housing projects. Linear regression analyzes the outcomes by using significance, so that if the response is less than
0.05 of significant quantities, it highlights the validity of risks occurrence. The results indicate that unexpected ground condition (under the category of environmental impacts), project delays (under the category of construction), bureaucracy (under the category of politic), contractual disputes between developer and landlord (under the category of law), weakness in management by inexperienced developer (under the category of management), and financial crisis (under the category of finance) are identified as the most significant risks that may lead to the issues associated with abandoned housing projects in Malaysia.

3.1.4. Additional Risk Mentioned by Respondents. Three additional risks were mentioned by respondents under the category of materials and economy. Materials are considered as important factors in any construction projects. It is essential to ensure that the quantities of material supply are sufficient to cover all construction work at project site. For this category, 
TABLE 7: Response on management.

\begin{tabular}{|c|c|c|c|c|c|}
\hline Construction & Probability & Frequency & Percent & Valid percent & Cumulative percent \\
\hline \multirow{6}{*}{$\begin{array}{l}\text { Weakness in management by } \\
\text { inexperienced developer }\end{array}$} & Very low probability & - & & & \\
\hline & Low probability & - & & & \\
\hline & Moderate probability & - & & & \\
\hline & High probability & 21 & 52.5 & 52.5 & 52.5 \\
\hline & Very high probability & 19 & 47.5 & 47.5 & 100 \\
\hline & Total & 40 & 100 & 100 & \\
\hline \multirow{6}{*}{$\begin{array}{l}\text { Weakness in management by } \\
\text { inexperienced contractor }\end{array}$} & Very low probability & - & & & \\
\hline & Low probability & 1 & 2.5 & 2.5 & 2.5 \\
\hline & Moderate probability & 22 & 55 & 55 & 57.5 \\
\hline & High probability & 17 & 42.5 & 42.5 & 100 \\
\hline & Very high probability & - & & & \\
\hline & Total & 40 & 100 & 100 & \\
\hline \multirow{6}{*}{$\begin{array}{l}\text { Delay in work due to management } \\
\text { failure by third party }\end{array}$} & Very low probability & - & & & \\
\hline & Low probability & 5 & 12.5 & 12.5 & 12.5 \\
\hline & Moderate probability & 23 & 57.5 & 57.5 & 70 \\
\hline & High probability & 9 & 22.5 & 22.5 & 92.5 \\
\hline & Very high probability & 3 & 7.5 & 7.5 & 100 \\
\hline & Total & 40 & 100 & 100 & \\
\hline \multirow{6}{*}{ Risks caused by subcontractor } & Very low probability & - & & & \\
\hline & Low probability & 5 & 12.5 & 12.5 & 12.5 \\
\hline & Moderate probability & 17 & 42.5 & 42.5 & 55 \\
\hline & High probability & 16 & 40 & 40 & 95 \\
\hline & Very high probability & 2 & 5 & 5 & 100 \\
\hline & Total & 40 & 100 & 100 & \\
\hline \multirow{6}{*}{ Partner withdrawals from joint venture } & Very low probability & - & & & \\
\hline & Low probability & 2 & 5 & 5 & 5 \\
\hline & Moderate probability & 16 & 40 & 40 & 45 \\
\hline & High probability & 12 & 30 & 30 & 75 \\
\hline & Very high probability & 10 & 25 & 25 & 100 \\
\hline & Total & 40 & 100 & 100 & \\
\hline
\end{tabular}

two risks were recognized by respondents that are response on delay of material supply to site and shortage of material supply.

The stability of economy in a country also helps the construction firm to develop the housing projects more efficiently. The risk of economic crisis, such as inflation, was also identified by respondents as a serious factor contributing to abandoned housing projects. All respondents believed that such risks might occur in anytime during the project and therefore the parties involved in housing industry need to take necessary actions in order to mitigate such risk before it ends up being the cause of problems associated with abandoned housing projects.

\subsection{Interview Session}

3.2.1. Respondents Background. For this study ten respondents were selected which consist of 4 developers, 2 contractors, 1 from government agency, and 3 from private agency who have more than 10 years of working experience in construction industry.

3.2.2. Interviewee's Response on Selected Questions Is Described in Table 9. See Table 9.

\section{Discussions and Solutions in Mitigating Risks}

From the perspective of environmental impacts, we can conclude that there are many risks that contribute to the occurrence of abandoned housing projects. The problems such as unforeseen ground conditions would cause delay disruption on construction activities and may lead to problems associated with abandoned housing projects. Other studies also stated that unexpected ground conditions are among the most important factors contributing to problems associated with abandoned housing project [16-18]. Under such 
TABLE 8: Response on finance.

\begin{tabular}{|c|c|c|c|c|c|}
\hline Construction & Probability & Frequency & Percent & Valid percent & Cumulative percent \\
\hline \multirow{6}{*}{ Late payment to contractor } & Very low probability & 3 & 7.5 & 7.5 & 7.5 \\
\hline & Low probability & 2 & 5 & 5 & 12.5 \\
\hline & Moderate probability & 13 & 32.5 & 32.5 & 45 \\
\hline & High probability & 18 & 45 & 45 & 90 \\
\hline & Very high probability & 4 & 10 & 10 & 100 \\
\hline & Total & 40 & 100 & 100 & \\
\hline \multirow{6}{*}{ Unstable finance by third party } & Very low probability & 2 & 5 & 5 & 5 \\
\hline & Low probability & 9 & 22.5 & 22.5 & 27.5 \\
\hline & Moderate probability & 15 & 37.5 & 37.5 & 65 \\
\hline & High probability & 2 & 5 & 5 & 70 \\
\hline & Very high probability & 12 & 30 & 30 & 100 \\
\hline & Total & 40 & 100 & 100 & \\
\hline \multirow{6}{*}{ Over budget } & Very low probability & - & & & \\
\hline & Low probability & 5 & 12.5 & 12.5 & 12.5 \\
\hline & Moderate probability & 7 & 17.5 & 17.5 & 30 \\
\hline & High probability & 14 & 35 & 35 & 65 \\
\hline & Very high probability & 14 & 35 & 35 & 100 \\
\hline & Total & 40 & 100 & 100 & \\
\hline \multirow{6}{*}{ Bankruptcy by developer } & Very low probability & - & & & \\
\hline & Low probability & - & & & \\
\hline & Moderate probability & - & & & \\
\hline & High probability & 20 & 50 & 50 & 50 \\
\hline & Very high probability & 20 & 50 & 50 & 100 \\
\hline & Total & 40 & 100 & 100 & \\
\hline \multirow{6}{*}{ Financial crisis } & Very low probability & - & & & \\
\hline & Low probability & 8 & 20 & 20 & 20 \\
\hline & Moderate probability & 5 & 12.5 & 12.5 & 32.5 \\
\hline & High probability & 8 & 20 & 20 & 52.5 \\
\hline & Very high probability & 19 & 47.5 & 47.5 & 100 \\
\hline & Total & 40 & 100 & 100 & \\
\hline
\end{tabular}

circumstance, many accidents might occur at project site. For example, accident causes the foreign worker's injury or death. Therefore, the construction parties need to implement and apply the safety features at project site to mitigate the accidents which negatively affect the performance of the project and contribute to the existence of abandoned housing projects.

Financial failure by developer is recognized as a construction constraint due to the reason that housing construction involves many phases and each phase requires large amounts of money. In such case, planning plays an important role in order to ensure the housing projects will be completed within the specified budget. Besides, the developers should make a proper decision to prevent their company from incurring the unnecessary cost. For example, when the cost of construction materials increases, the developer should ensure that they order the right quantities of materials supply, so that there will not be any wasted construction materials. Previous studies also claimed that financial problems faced by developers are a result of mismanagement and misuse of the finance by developers $[15,19,20]$.
From economic perspective, the Asian Financial Crisis in 1997 and 2007 had given impacts and challenges to housing industry at that time. The crisis had affected the developers until some of them had to wind up their organization due to incapability to withstand the high cost and stop their construction operation. Therefore, the parties involved in housing industry should be prepared to work efficiently under such circumstances. They should strengthen their organization financial stability and create an efficient financial management in order to prevent their developers from bankruptcy. Economic crisis or financial crisis often seems to be the main cause of abandoned housing projects $[1,9]$.

From the perspective of the law, it is worth to mention that the Malaysian housing and property industry is highly regulated [15], and it was also claimed that it is not a major risk that contributes to issues associated with abandoned housing projects. However it is claimed that the risks associated with the law still need to be considered by all parties at the stage of planning. In construction of any housing project, the parties involved in housing industry such as developers and 
TABLE 9: Interview response.

\begin{tabular}{ll}
\hline Types of responses towards & Details of respondents \\
\hline $\begin{array}{l}\text { Weakness in financial } \\
\text { abandoned housing projects. They believed that the problems of abandoned housing projects mostly } \\
\text { come from developers as they are considered the critical parties who carry out the process of } \\
\text { developing housing projects and therefore they should be able to manage their financial resources } \\
\text { efficiently. In fact, the respondents believed that the housing developers should be willing to take any } \\
\text { action required in dealing with risk involved in the project and manage it systematically. Financial } \\
\text { issues by developers in housing projects can lead to serious consequences that will prolong the progress } \\
\text { of housing project and subsequently will influence the overall performance of the housing project. It is, } \\
\text { therefore, crucial for developers to manage and maintain the capital flows in each phase of the } \\
\text { construction project to ensure that the project can be completed within allocated budget and time. }\end{array}$ \\
$\begin{array}{l}\text { Almost all of respondents agreed that the weakness in construction management by developers is one } \\
\text { of the factors contributing to the abandoned housing projects. Some examples of weakness in } \\
\text { construction management by developers were mentioned. For instance, it has been reported that some } \\
\text { of the developers inaccurately estimated the time to complete the project as well as the required } \\
\text { quantities of construction resources for the project due to the lack of real understanding of the laws } \\
\text { which resulted in abandoned housing projects. The respondent believed that such problems come from } \\
\text { the new and inexperienced developers. Hence, it was suggested that it is necessary for inexperienced } \\
\text { developers to learn the technical knowledge of construction management methods and practice them } \\
\text { in order to mitigate the failing conditions and to complete the projects within the schedule. }\end{array}$ \\
$\begin{array}{l}\text { Weakness in construction } \\
\text { management by developer }\end{array}$
\end{tabular}

All developers and nearly contractors agreed that economic crisis such as Asian Financial Crisis in 1997 can be considered as one of the causes of abandoned housing projects. They stated that economic crisis

Economic crisis such as can directly affect the construction organization and results in financial shortage. However, majority of Asian Financial Crisis respondents from government and private agencies believed that this is not a major factor contributing in abandoned housing projects as they are just seasonal causes and all parties involved in housing projects should be well-prepared in advance.

Half of respondents agreed that the shortage of construction materials is considered as one of the factors contributing to abandoned housing projects. They believed that the lack of construction

Shortage of construction materials brings negative impacts to any construction project, so that it affects overall progress of each phase of the project. It indeed forces contractors to leave the project site and subsequently leads to project delay and project being abandoned.

materials

Except developers who stated that not achieving target sales due to the high prices market is one of the

Not achieving target sales due to the high prices causes contributing to abandoned housing projects, other respondents believed that this is not a serious risk in housing industry because the abandoned housing projects in Malaysia are usually low to medium cost houses.

market

Again except developers who believed not achieving target sales due to the weakness in sales marketing is the cause of abandoned housing project, the rest of respondents did not agree on this statement.

Not achieving target sales due to the weakness in sales marketing

Housing development without feasibility studies Although they believed that sales marketing in housing development is an essential element in selling houses to buyers, it still cannot be considered as a major factor contributing to the issues of abandoned housing projects in Malaysia. A few suggestions on how to make a sales marketing become more effective were given including the developers should formulate, implement, and manage a comprehensive marketing plan from design, concept, and pre- and postsales processes for any housing development program in order to ensure that the target sales will be achieved.

Majority of respondents agreed that housing development without feasibility studies can be another cause of abandoned housing projects. They believed that the feasibility study is an important matter and should be taken into consideration even though it is just an option for developers. Moreover, they stated that, without the feasibility study, the problems of abandoned project might become more serious. The feasibility study can help the developers before they make any important strategic decision for developing the housing projects. Feasibility study is a detailed analysis by company and it is conducted in order to predict the results of a specific future course of action and to determine whether a certain plan of action is feasible and whether or not it is economically worth doing. For example, a company might perform a feasibility study to evaluate a proposed change in location, a purchase of major equipment, or the introduction of a new technology and service. In such situations, a feasibility study will help developers to understand the impact of any major changes in the project. A good feasibility study would also review a company's strengths and weaknesses, its position in the marketplace, and its financial situation. Throughout this process, the feasibility study will show developers the various consequences and impacts associated with the plan of action and automatically will prevent the probability of project from being abandoned. 
TABLe 9: Continued.

\begin{tabular}{ll}
\hline Types of responses towards & Details of respondents \\
\hline $\begin{array}{l}\text { Poor construction } \\
\text { management by contractor }\end{array}$ & $\begin{array}{l}\text { Almost all of respondents believed that poor construction management by contractor is also a factor of } \\
\text { any construction housing project and responsible for monitoring the construction work at site } \\
\text { regularly. Inexperienced contractor can bring many problems to the project, such as shortage or excess } \\
\text { of construction materials due to the misestimation, taking the unskilled workers at project site, and lack } \\
\text { of equipment and machinery which enable the construction team to complete each phase of project } \\
\text { within specified time. The poor performance of contractor will clearly cause delays to the projects and } \\
\text { induce the problems associated with abandoned housing projects. }\end{array}$ \\
\hline $\begin{array}{l}\text { The excess of housing units } \\
\text { supply }\end{array}$ & $\begin{array}{l}\text { Almost half of respondents agreed that excess of housing units supply may be considered as one of the } \\
\text { causes contributing to abandoned housing projects; however, they mentioned that this problem is rare } \\
\text { to happen and it can still be prevented earlier through proper planning by parties involved in housing } \\
\text { projects. Developers are also encouraged to do feasibility studies on the project site before making any } \\
\text { decision for housing development. }\end{array}$ \\
\hline $\begin{array}{l}\text { Again half of respondents agreed that the financial failure can also cause the problems associated with } \\
\text { abandoned housing projects. The respondents commented that the responsibility of contractor is very } \\
\text { critical in executing any housing projects. A contractor should have a good construction planning and } \\
\text { also efficiently progress the construction works as planned. However, a weak financial position may } \\
\text { result in a contractor's financial failure, leaving the contractor unable to fulfill the requirement of the } \\
\text { contract which will lead to the occurrence of abandoned housing projects. }\end{array}$
\end{tabular}

contractors must be aware of any changes in the act of law that are related to the housing industry. It is important to ensure that they will not face any difficulties and problems in developing housing projects.

From the political aspects, it cannot be denied that stable political conditions in a country will assist the housing industry to rapidly grow from time to time. Other studies also recognized the political stability in a country as a mitigating and preventing factor to prevent the housing project from being abandoned [9]. The good political conditions will facilitate the construction process and avoid any problems during the development. There are also some other obstacles in the housing projects such as the difficulties in obtaining permits for foreign workers which might lead to the shortage of labour or manpower in construction sector. This situation occurs because the construction industry requires many foreign workers at project site. In addition, the problems of bureaucracy should be faced by parties involved in housing projects, especially the developers. Sometimes, the developers need to face many procedures in developing housing projects and this obviously required them to spend a lot of time and effort to handle them efficiently. Sometimes, it is hard for developers to continue the construction process under such difficult conditions, and, as a result, the project may not proceed within the time specified and eventually lead to the problems associated with abandoned housing projects.

There are also problems associated with abandoned housing project due to the contractor's failure. A contractor is an important person in construction sector who needs to have a good plan in construction activities. However, a contractor and subcontractor sometimes create problems to developers such as hiring unqualified workers, shortage or excess of materials supply at site, financial failure by contractor, and delay of project. The entire problems will affect the overall performance of housing projects especially when these housing projects involve inexperienced contractors. To overcome such problems, the developers must give the responsibilities of construction works to the potential and qualified contractors based on their past experience in terms of manpower, reputation, and financial stability. Other researchers also believe that the factor of inexperienced contractor is one of the important factors contributing to abandoned housing projects in construction industry $[9,15]$.

\section{Conclusion}

This study examined the risks contributing to the issues associated with abandoned housing projects through a combination of qualitative and quantitative methods of literature review, questionnaire survey, and interview. Based on the findings, there are many risks involved in housing project, such as risks related to environmental impacts, construction, politics, law, management, finance, materials, and economy. It was also found that under the categories of the abovementioned risks, the probability of risks from unexpected ground condition, project delays, bureaucracy, contractual disputes between developer and landlord, weakness in management by inexperienced developer, and financial crisis is very high, so that these risks are considered as the most significant risks leading to the problems associated with abandoned housing projects in Malaysia. Moreover, it was found that delay of material supply to site, shortage of material supply, and also economic crisis are recognized as major factors contributing to problems leading to the project being abandoned.

The results from the interviews show that weakness in financial and construction management by developers, housing development without feasibility studies, and poor construction management by contractor are the most critical factors that cause the problems associated with housing abandonment. Previous studies also identified mismanagement, which usually happens due to the lack of experience of developers and/or contractors, as one of the factors contributing 
to abandoned housing projects $[15,19]$. Moreover, the lack of proper feasibility studies might result in inaccurate supply and demand forecasting for certain types of properties. Therefore, feasibility studies are required to be conducted in order to determine the suitable type of development in terms of its physical complexities, planning requirements, and economics.

From the results of this study, it can be concluded that the problems associated with abandoned housing project need an effective system of risk management strategies as the housing industry in Malaysia is rapidly growing from day to day and all the risks pertaining to abandoned housing projects should be given a great attention. These risks can be recognized earlier and be efficiently managed if all parties involved in housing industry cooperate in dealing with this matter.

\section{Conflict of Interests}

The authors declare that there is no conflict of interests regarding the publication of this paper.

\section{References}

[1] R. Carrero, G. Malvárez, F. Navas, and M. Tejada, "Negative impacts of abandoned urbanisation projects in the Spanish coast and its regulation in the Law," Journal of Coastal Research, no. 56, pp. 1120-1124, 2009.

[2] J. H. M. Tah and V. Carr, "Knowledge-based approach to construction project risk management," Journal of Computing in Civil Engineering, vol. 15, no. 3, pp. 170-177, 2001.

[3] S. M. Latham, Constructing the Team, HM Stationery Office, 1994.

[4] J. G. Perry and R. W. Hayes, Construction Project-Know the Risks, Chartered Mechanical Engineer, 1985.

[5] H. Abdul Rahman, A. M. Alashwal, M. Ayub, and A. A. Abdullah, "Abandoned housing projects in Malaysia: pressing issues during the rehabilitation process," International Journal of Architectural Research, vol. 7, no. 1, pp. 1-9, 2013.

[6] S. V. Doraisamy, Z. A. Akasah, and R. Yunus, "A review on abandoned construction projects: causes and effects," in Proceedings of the International Integrated Engineering Summit (IIES '14), pp. 1-4, December 2014.

[7] H. A. Odeyinka and A. Yusif, "The causes and effects of construction delays on completion cost of housing projects in Nigeria," Journal of Financial Management of Property and Construction, vol. 2, no. 3, pp. 31-44, 1997.

[8] P. Bryne and D. Cadman, Risk, Uncertainty and DecisionMaking in Property, Spon, London, UK, 1984.

[9] Y. E. Hoe, Causes of abandoned construction projects in Malaysia [Ph.D. thesis], Department of Surveying, Faculty of Engineering and Science, Universiti Tunku Abdul Rahman, Petaling Jaya, Malaysia, 2013.

[10] A. Yusoff, The evaluation of site quality management system in construction industry [Ph.D. thesis], Faculty of Built Environment, Universiti Teknologi Malaysia, Johor, Malaysia, 2005.

[11] Z. Manaf, M. Diah, and M. Lizam, “The management of property development risks in Malaysia-the property development process: a review," in Proceedings of the 12th Annual Pacific-RIM Real Estate Society Conference, Auckland, New Zealand, January 2006.
[12] M. Dahlan and N. Hilal, "Abandoned housing projects in Malaysia: legal issues relating to the housing developer's advertisement and sale permit," in Proceedings of the 6th International Borneo Business Conference (iBBC '14), pp. 1-9, Kuching, Malaysia, August 2014.

[13] A. A. Abdullah and H. Abdul Rahman, "Identification of relevant risks in abandoned housing projects in Malaysia: a qualitative study," Procedia-Social and Behavioral Sciences, vol. 62, pp. 1281-1285, 2012.

[14] H. C. Siong, Evaluation of housing estate development in relation to housing supply in Malaysia (with reference to urban management and housing approval system) [Degree of Doctor of Engineering], Toyohashi University of Technology, Toyohashi, Japan, 1994.

[15] M. S. Khalid, Abandoned housing development: the Malaysian experience [Ph.D. thesis], Heriot-Watt University, Edinburgh, Scotland, 2010.

[16] S. M. Dissanayaka and M. M. Kumaraswamy, "Evaluation of factors affecting time and cost performance in Hong Kong building projects," Engineering Construction and Architectural Management, vol. 6, no. 3, pp. 287-298, 1999.

[17] Y. Frimpong, J. Oluwoye, and L. Crawford, "Causes of delay and cost overruns in construction of groundwater projects in a developing countries; Ghana as a case study," International Journal of Project Management, vol. 21, no. 5, pp. 321-326, 2003.

[18] S.-U.-R. Toor and S. O. Ogunlana, "Problems causing delays in major construction projects in Thailand," Construction Management and Economics, vol. 26, no. 4, pp. 395-408, 2008.

[19] F. Ibrahim, Faktor-faktor kritikal bagi pemulihan projek perumahan terbengkalai [Ph.D. dissertation], Faculty of Civil Engineering, Universiti Teknologi Malaysia, 2006.

[20] P. W. Ihuah and A. Benebo, "An assessment of the causes and effects of abandonment of development projects on real property values in Nigeria," International Journal of Research in Applied, Natural and Social Sciences, vol. 2, no. 5, pp. 25-36, 2014. 

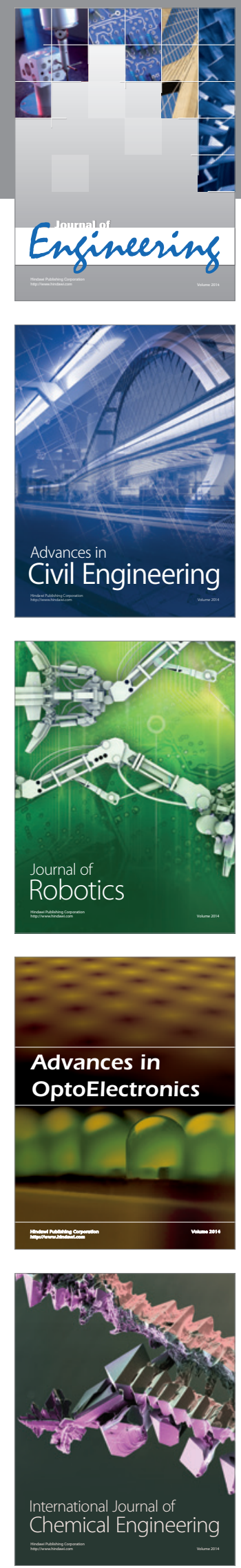

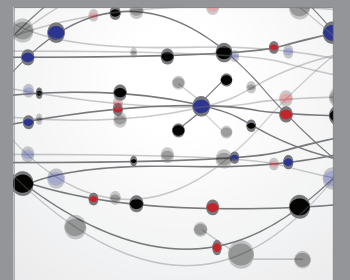

The Scientific World Journal
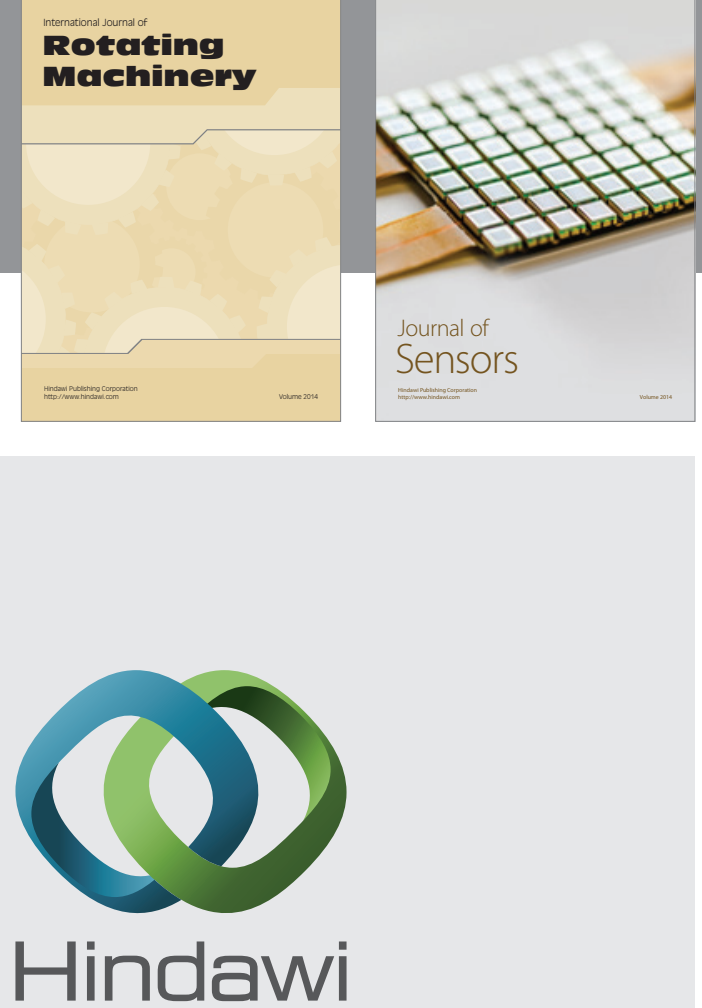

Submit your manuscripts at http://www.hindawi.com
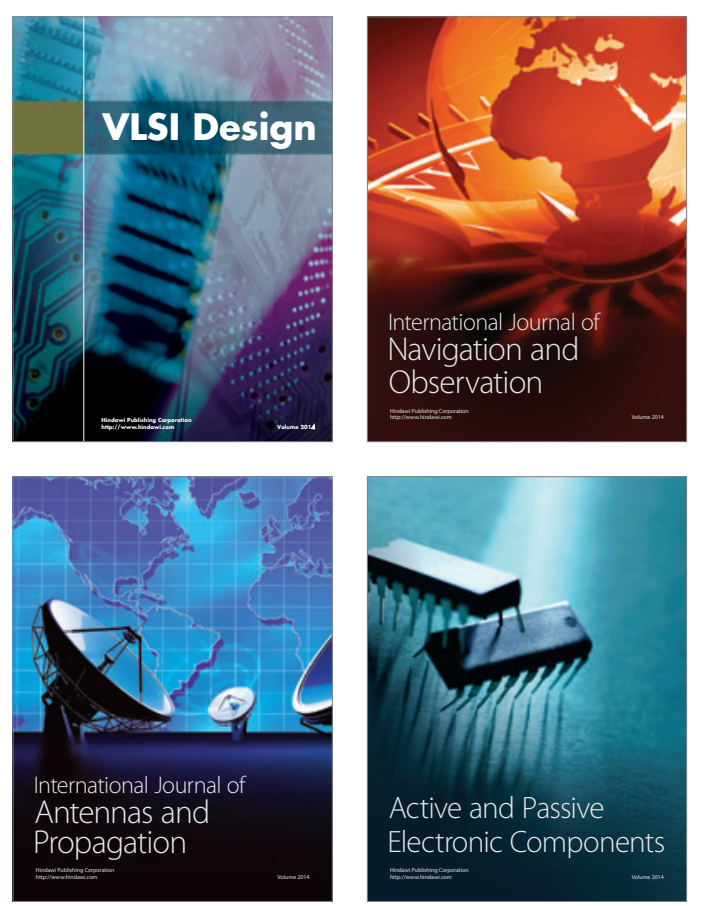
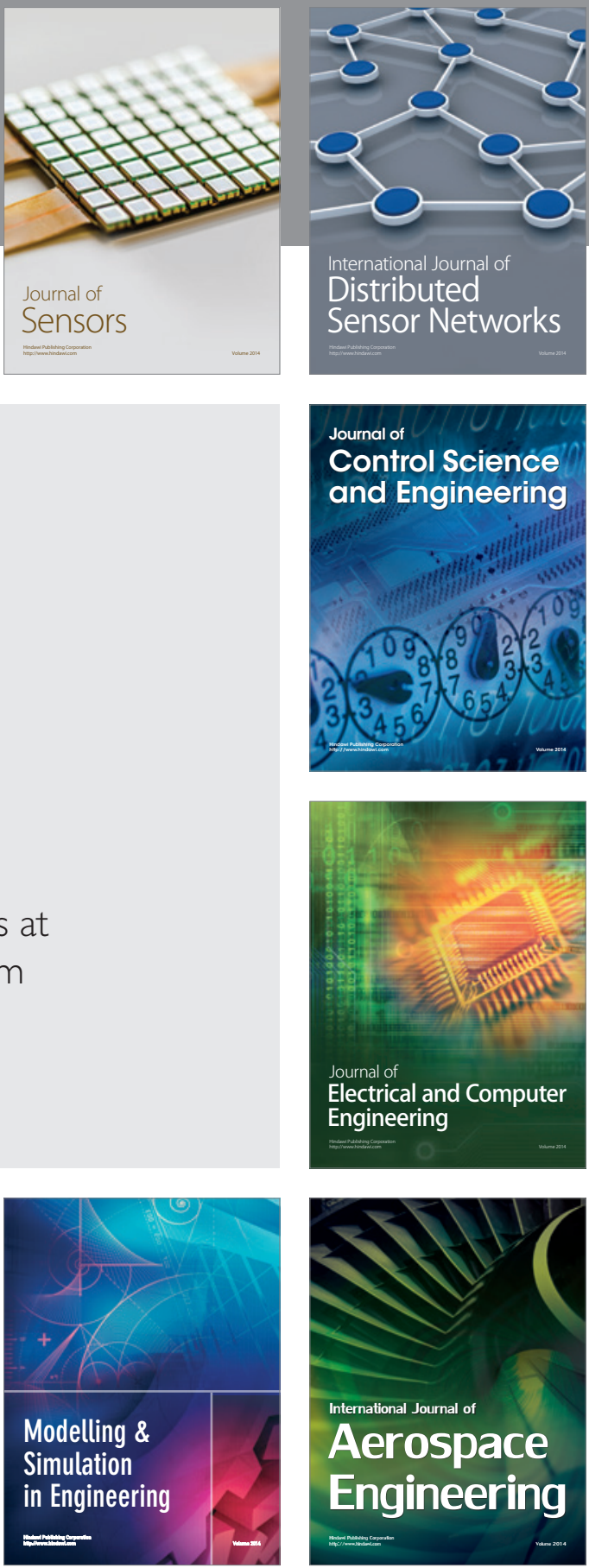

Journal of

Control Science

and Engineering
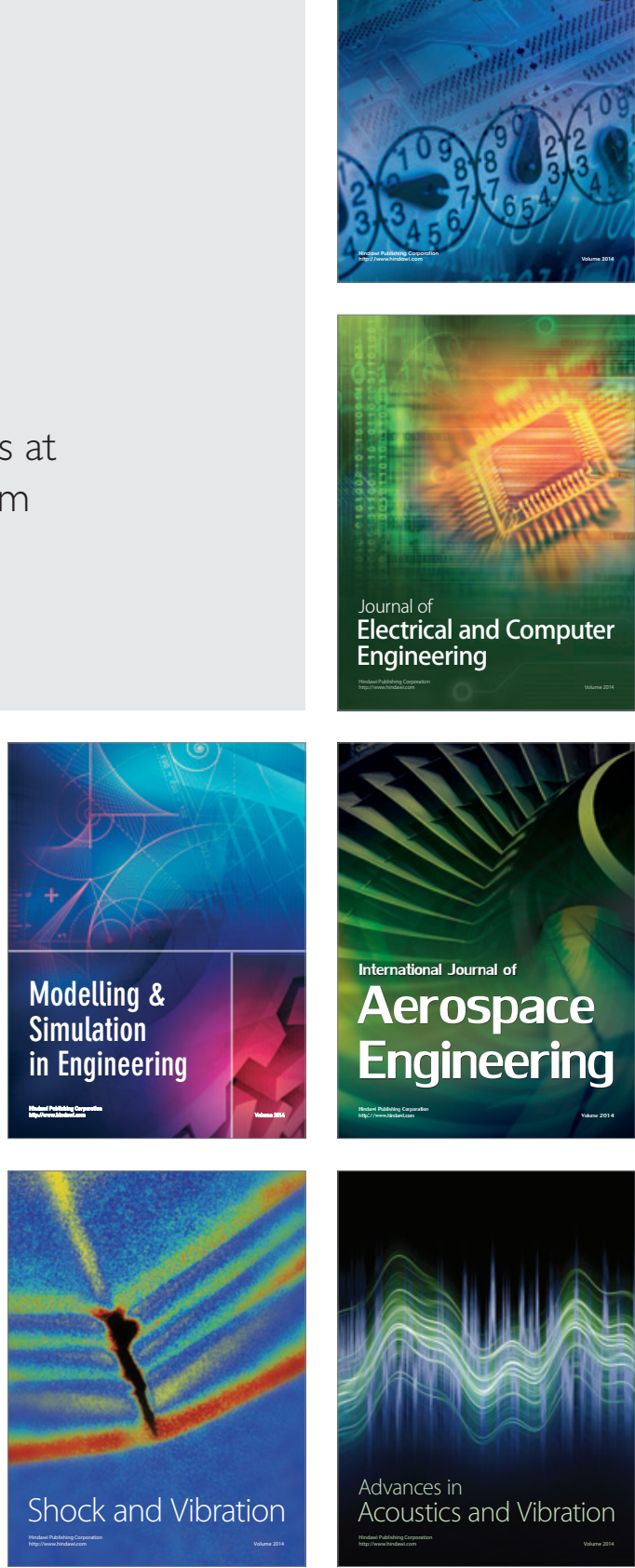